\title{
Determination of the circulation depth and reservoir tem- peratures of thermal waters in the southern Spitsbergen using geothermometry
}

Institute of Geological Sciences, University of Wrocław, P1. M. Borna 9, 50-204 Wrocław, Poland;

*Corresponding author,E-mail: tomasz.olichwer@uwr.edu.pl

(Received: August 23, 2021; Revised accepted: November 22, 2021)

https://doi.org/10.18814/epiiugs/2021/021034

The aim of article is determining the circulation depth and reservoir temperatures of thermal springs in the southern Spitsbergen using selected geothermometers which are in particular suitable for systems under low enthalpy conditions. For the analysis of the thermal waters circulation, the six thermal springs were selected. The conducted calculations of reservoir water temperatures for the thermal outflows showed that the most homogeneous temperature range was obtained for the $\mathrm{Na}-\mathrm{K}-\mathrm{Ca}, \mathrm{K}-\mathrm{Mg}, \mathrm{Ca}-\mathrm{Mg}$, and $\mathrm{Na-Li} \mathrm{geothermometers} \mathrm{as} \mathrm{well} \mathrm{as} \mathrm{for} \mathrm{the} \mathrm{silica} \mathrm{geother-}$ mometer using the mixing model. The derived temperature values demonstrate the existence of two depth zones of thermal water formation. The first shallower zone, up to a depth of $1.1 \mathrm{~km}$, is associated with water circulation in the fault zones of metamorphosed carbonate rocks of the Hecla Hoek succession in the region of the Hornsund fjord and Raudfjellet massif. This zone is characterized by reservoir water temperatures of about $40^{\circ} \mathrm{C}$. The second deeper zone of thermal waters in the Sørkappland area (Stormbukta area), with a temperature of about $80^{\circ} \mathrm{C}$, corresponds to the groundwater reservoir located at a depth of $2.3 \mathrm{~km}$. The thermal waters here are associated with sedimentary rocks of the late Paleozoic and early Mesozoic periods. Na-K geothermometer gives results consistent with the above-mentioned geothermometers only in the case of mature or partially mature waters (only Sørkappland area). Furthermore the original silica content $(30 \mathrm{mg} / \mathrm{kg})$ in the hot water, estimated by authors using mixing model, indicates that in the thermal water outflows of southern Spitsbergen the percentage of cold shallow circulation waters is about $85 \%$, while the percentage of deep circulation thermal waters is $15 \%$. The application of comprehensive solutions such as the simultaneous use of a number of different geothermometers, supported by the mixing models, allows us to determine temperatures in deep hot water reservoirs.

\section{Introduction}

Spitsbergen thermal waters have been the subject of hydrogeological research for more than 100 years. The first documented study on thermal springs in Spitsbergen dates back to the end of the 19th century and it was conducted in the Bockfjord area (northern Spitsbergen). The springs in this area are the most northerly located thermal springs in the world. During this first study, water temperatures of 24.5 and $28.3^{\circ} \mathrm{C}$ were recorded in the Jotun and Troll springs, respectively (Hoel and Holtedahl, 1911). As far as the southern part of Spitsbergen is concerned, in turn, the first descriptions of thermal water springs date back to the 1920's and 40's (Werenskiold, 1920; Orvin, 1944). A significant increase in interest in Spitsbergen hot springs among scientists, particularly hydrogeologists, has been observed since the 1970's. Their research has covered a wide thematic range, from hydrochemistry (Banks et al., 1998) through spring regime (Pociask-Karteczka, 1990), isotopic composition (Szynkiewicz et al., 2020), and geological situation (Birkenmajer, 1990) to spring microbiology (Lauritzen and Bottrell, 1994).

In the polar regions, groundwater circulation is generally accepted to occur within three zones (Williams and van Everdingen, 1973); i.e. above the permafrost (suprapermafrost), inside the permafrost (intrapermafrost), and below the permafrost (subpermafrost). The groundwater circulation zone above the permafrost can be termed as the shallow circulation zone, whereas the waters inside and below the permafrost as the intermediate zone. In the study area (coast of SW Spitsbergen), the permafrost is typically $100-150 \mathrm{~m}$ thick (Wawrzyniak et al., 2016), but in interior mountains more than $500 \mathrm{~m}$ thick (Humlum et al., 2003).

The groundwater flow in the suprapermafrost zone occurs in the active layer that thaws during spring and early summer. Precipitation, thawing permafrost and subglacial water discharge from the glaciers are the main sources of water for this system. The water temperature in this system is close to $0^{\circ} \mathrm{C}$. The characteristics of the shallow circulation zone of the Spitsbergen are very well described, supported by a number of publications, for example Wadham et al. (1998), Cooper et al. (2002) and Szynkiewicz et al. (2013). 
The similarly richly described are the groundwater circulating in the intermediate zones, which are regarded as confined by an overlying aquiclude of permafrost (Haldorsen et al., 1996; Lauritzen, 1996). Under favourable conditions, if the piezometric head in the confined subpermafrost groundwater system exceeds the ground level, the groundwater of this system can discharge to the surface, either via karst systems, via tectonic fracture zones or faults (Van Everdingen, 1990). The water outflow temperature is typically about $4^{\circ} \mathrm{C}$.

The relatively poorly explored is a deep groundwater circulation zone, which is the main topic of this article. This zone is defined by systems of tectonic discontinuities where the waters from the first two zones can infiltrate to significant depths $(>1,500 \mathrm{~m})$ and subsequently escape to the land surface through these tectonic discontinuities (Van Everdingen, 1990; Haldorsen et al., 1996). Numerous thermal springs, with outflow temperatures ranging from $8-14^{\circ} \mathrm{C}$ (southern Spitsbergen) (Olichwer et al., 2013) to more than $25^{\circ} \mathrm{C}$ (northern Spitsbergen), are associated with this zone (Banks et al., 1998, 1999).

Banks et al. (1998), among others, conducted research to investigate the depth of thermal water deep circulation in northern Spitsbergen. His study carried out in the Bockfjorden area (Jotun and Troll springs) showed that the water was discharged from hot salty water reservoirs with temperatures ranging $130-180^{\circ} \mathrm{C}$ in the case of the Troll spring, with a $10-30 \%$ proportion of salty thermal water, diluted by $70-90 \%$ cold water. At a geothermal degree of $0.079^{\circ} \mathrm{C} / \mathrm{m}$, this corresponds to a circulation depth of 1.6-2.3 km (Banks et al., 1998). Moreover, this study suggests that the Jotun springs originate from a thermal water source with a temperature higher by several dozen degrees Celsius than in the case of the Troll springs.

There are no articles in the literature describing the deep circula- tion of thermal waters in southern Spitsbergen. The northern part is better recognized. The aim of this article is to expand the hydrogeological knowledge by determining temperatures in the reservoirs of thermal waters discharged to the ground surface and circulation depth in the area of Sörkappland and the Hornsund fjord located in southern Spitsbergen (Fig. 1).

One of the research tools to achieve this aim are geothermometers. Temperature in a thermal water reservoir can be estimated based on the tested chemical composition of such water near the ground surface or at the discharge point. The use of geothermometers is based on the assumption that the components of the minerals making up the rocks of the reservoir which are dissolved in the water are in chemical equilibrium with these minerals and that this equilibrium has not been disturbed during water ascent from the reservoir to the surface.

Application of both chemical and isotopic geothermometers is a quick way to assess geothermal energy in an groundwater reservoir. Nonetheless, interpretation of obtained results is not easy. In some cases, exact temperatures inside a reservoir can be directly obtained by geothermometers. In other cases, however, temperature estimation should use models for mixing thermal waters from the reservoir bottom with cold shallow circulation waters. If chemical equilibrium has been attained after such waters have been mixed, geothermometers will indicate the temperature of the mixed water, not that of the hot water component (Fournier, 1977).

Geothermometers often produce divergent results, which may be attributable to the fact that chemical equilibrium has not been fully established. Generally, assessment of reservoir temperature should be made based on several geothermometers in order to obtain the most probable result.

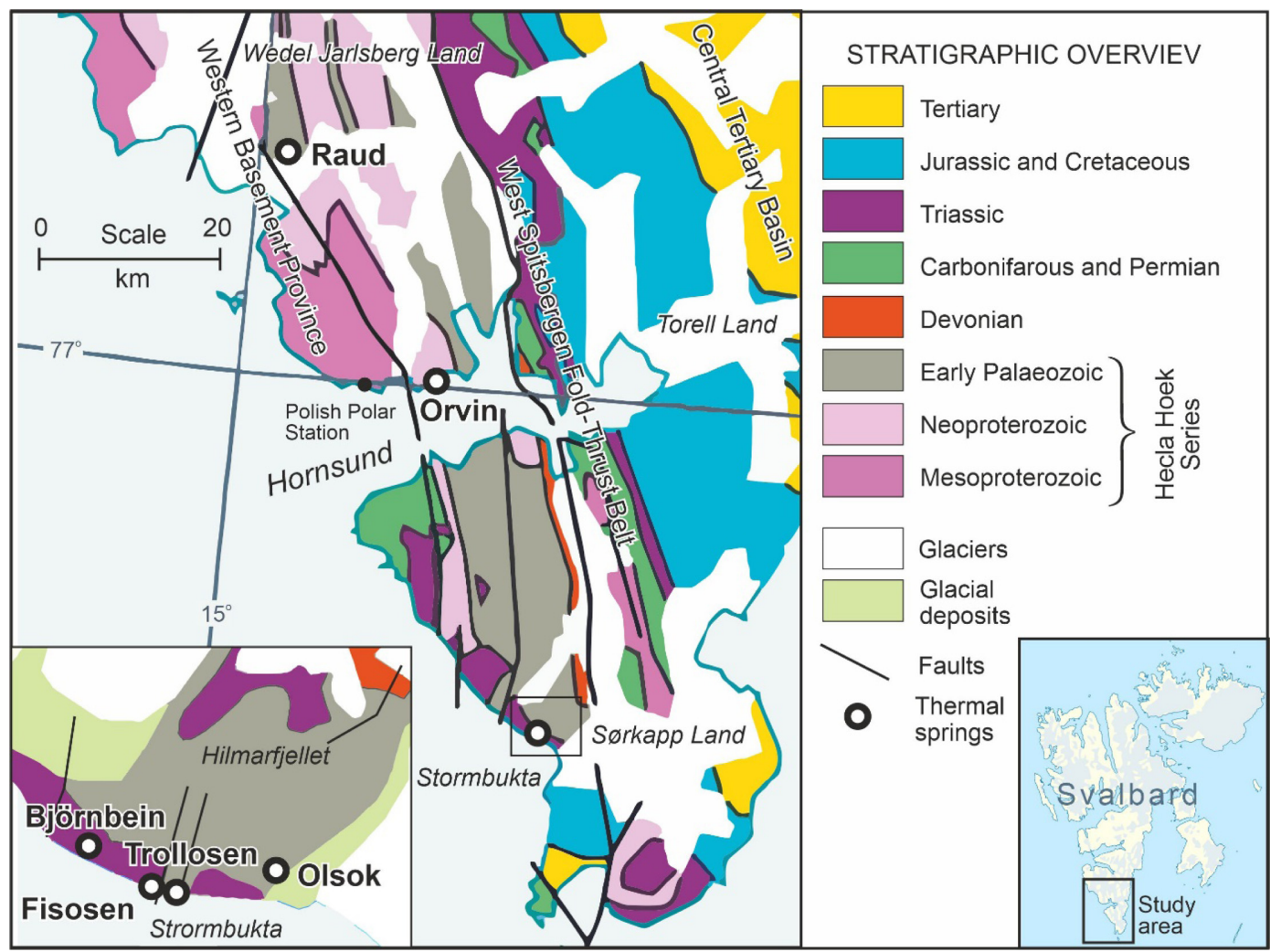

Figure 1. Map of the study area. 
Most chemical and isotopic geothermometers have been calibrated for high temperature thermal waters of volcanic origin. Application of such geothermometers for low enthalpy waters (discharge temperatures below $50^{\circ} \mathrm{C}$ ) raises a number of controversies with regard to their accuracy. In this article, the authors decided to indicate geothermometers that can be best used for the waters that are found in polar areas, which are not of volcanic origin.

For the analysis of the thermal waters circulation using geothermometers, the six thermal springs that had been previously studied by researchers (Olichwer et al., 2013; Olichwer and Tarka, 2018) were selected. A more detailed description of selected springs can be found later in the article.

In the introductory chapters of this paper the natural conditions of research area and the thermal springs used in the article were described. Then, the chapter "Methods" presents geothermometers used to determining the temperatures of the deep thermal water reservoirs of the study area. In the second part of the article, the obtained temperature results were described and discussed. On the basis of selected geothermometers, which best reflect the low enthalpy conditions, the circulation depths of thermal waters were determined.

\section{Study Area}

The study area covers southern Spitsbergen: the Hornsund fjord area, the foothills of the Raudfjellet massif, and the Sörkappland area (Stormbukta) (Fig. 1). Meridional mountain ranges and coastal lowlands are predominant in the study area landscape. The current landscape was formed by recurrent Quaternary glaciations. In the Spitsbergen area, four main geological units can be distinguished (Fig. 1): a) a Tertiary sedimentary basin; b) a platform built of rocks from the Carboniferous to the Cretaceous; c) a Devonian sedimentary basin; and d) metamorphic bedrock (Proterozoic, early Paleozoic), but only the three latter ones are found in the study area.

Strongly metamorphosed rocks of the Hecla Hoek succession with a thickness of 15-17 km are the oldest in the study area (PrecambrianLower Ordovician). This lithostratigraphic complex is represented by paragneisses, mica slates with limestones, quartzites, amphibolite slates, and gneisses (Birkenmajer, 1990). From the Devonian through the Mesozoic, sedimentary clastic and carbonate rocks with evaporite interbeds formed on crystalline rocks. The thickness of platform sediments is in the order of several kilometers (Birkenmajer, 1990). The raised sea beaches, terraces, and cliffs, which are characteristic features for the coastal area of Spitsbergen, formed during the late Pleistocene and Holocene period.

In the area described, we also deal with a rich tectonic history whose beginnings date back to the Precambrian (Harland, 1997). Its effect is a large amount of faults and discontinuities that substantially affect the groundwater circulation, which applies in particular to subpermafrost and thermal waters associated with deep circulation.

\section{Thermal Waters of Southern Spitsbergen}

Thermal waters in the area of Raudfjellet and the Hornsund fjord are represented by the Raud and Orvin karst springs (Fig. 1), with their mineralization of up to $400 \mathrm{mg} / \mathrm{dm}^{3}$ (Olichwer et al., 2013). The thermal outflows at the foot of Raudfjellet were discovered in 1973 by an expedition of the Wrocław University headed by S. Baranowski (Migała and Sobik, 1982). This is an outflow zone at the edge of the Torell Glacier, at the place where crystalline carbonate rocks of the Hecla Hoek succession occur. At that time, the water outflow temperature was recorded to be $12.1^{\circ} \mathrm{C}$ (Krawczyk, 1989).

The Orvin spring, at the foot of Gnalberget, is located in the area of the Sofiekammen massif, which is composed of marbles and limestones of the Hecla Hoek succession. The Orvin spring waters are discharged in the littoral zone composed of gravel sediments at several sites along a length of about 40 meters. The discharge capacity of the individual outflows ranges from 0.05 to more than $1 \mathrm{dm}^{3} / \mathrm{s}$, with their total capacity of about $15 \mathrm{dm}^{3} / \mathrm{s}$. These outflows are visible only during low tide. This spring was first described by Orvin in 1944, who recorded a water temperature of $12^{\circ} \mathrm{C}$.

Another 4 sites with a mineralization of more than $1 \mathrm{~g} / \mathrm{dm}^{3}$ are found in the area of Sörkappland, at the foot of the Hilmarfjellet massif. In geological terms, these outflows are associated with limestones and dolomites of the Hecla Hoek succession and younger sedimentary rocks from the late Paleozoic-early Mesozoic period.

A spring located in the lateral moraine of the Olsok Glacier, with the same name and a discharge capacity ranging $150-450 \mathrm{dm}^{3} / \mathrm{s}$, is the most southerly located. Pulina (1977) recorded a mineralization of 8.6 $\mathrm{g} / \mathrm{dm}^{3}$ in this spring, which is the highest value found thus far in Spitsbergen. It is one of the coldest springs and has the lowest values of $\mathrm{pH}$ and Eh; moreover, it gives off a strong $\mathrm{H}_{2} \mathrm{~S}$ odor. The increased hydrogen sulfide content is the effect of the coincidence of slow leaching of chemical compounds from the rocks by the flowing water and the flow of water through biologically active deposits occurring at the spring (Olichwer et al., 2013).

The Trollosen karst spring (a cave discharge point) is found to the north east of the Olsok site; with its average discharge capacity of $10 \mathrm{~m}^{3} / \mathrm{s}$, it is the largest spring in Spitsbergen. The water outflow temperature is $4^{\circ} \mathrm{C}$. About $400 \mathrm{~m}$ to the north from the Trollosen spring, a small thermal spring is located, called Fisosen, which was found in the 1990's by Lauritzen (1996). The water outflow temperature is $13-15^{\circ} \mathrm{C}$.

A vast outflow zone, called Bjørnbein, is located northernmost of all the sites in the Sörkappland area, in a sea terrace (Bjørnbeinflya). 3 outflow sites, with a water temperature of $15.2-16.5^{\circ} \mathrm{C}$, were described here in the 1970's and 80's. These waters were of the Cl-Na type and had a mineralization of more than $1 \mathrm{~g} / \mathrm{dm}^{3}$ (Pulina, 1977; Krawczyk, 1996). However, during a study conducted in the 1990's these outflow sites were found to be dry (Lauritzen, 1996). A study carried out in 2006 revealed in this area a vast outflow zone where water with low mineralization $\left(346 \mathrm{mg} / \mathrm{dm}^{3}\right)$ and temperature reaching $13^{\circ} \mathrm{C}$ was discharged (Olichwer et al., 2013; Olichwer and Tarka, 2018).

In southern Spitsbergen, the thermal waters are predominantly associated with subpermafrost waters being mixed with the shallower waters of melting permafrost and glaciers (Haldorsen et al., 1996). Furthermore, in the case of thermal waters with the dominant ions $\mathrm{Cl}^{-}$ and $\mathrm{Na}^{+}$, their chemical composition is affected by subpermafrost hot brines (Lauritzen and Bottrell, 1994; Olichwer and Tarka, 2018). In three out of the four studied thermal water outflows located in the Sörkappland area (Olsok, Fisosen, Trollosen), a mineralization of more than $1 \mathrm{~g} / \mathrm{dm}^{3}$ was recorded. The fourth site, Bjørnbein, with a mineral- 
Table 1. List of parameters of the southern Spitsbergen thermal springs

\begin{tabular}{|c|c|c|c|c|}
\hline Spring name & Dominating ions & Mineralization $\left[\mathrm{mg} / \mathrm{dm}^{3}\right]$ & Spring temperature $\left[{ }^{\circ} \mathrm{C}\right]$ & Location \\
\hline Orvin & $\mathrm{Cl}^{-}-\mathrm{Na}^{+}$ & 378 & 13.0 & Hornsund \\
\hline Raud & $\mathrm{Cl}^{-}-\mathrm{HCO}_{3}^{-}-\mathrm{Na}^{+}$ & 228 & 11.9 & Raudfjellet \\
\hline Olsok & $\mathrm{Cl}^{-}-\mathrm{Na}^{+}$ & 4030 & 9.3 & Sørkappland \\
\hline Trollosen & $\mathrm{Cl}^{-}-\mathrm{Na}^{+}$ & 1526 & 3.4 & Sørkappland \\
\hline Fissosen & $\mathrm{Cl}^{-}-\mathrm{Na}^{+}$ & 3420 & 15.4 & Sørkappland \\
\hline Bjørnbein & $\mathrm{HCO}_{3}^{-}-\mathrm{Na}^{+}-\mathrm{Ca}^{+}$ & 346 & 13.9 & Sørkappland \\
\hline
\end{tabular}

Data based on the articles by Olichwer et al. (2013) and Olichwer and Tarka (2018)

ization of $346 \mathrm{mg} / \mathrm{dm}^{3}$, is characterized by more diverse chemical composition and a large proportion of the ions $\mathrm{HCO}_{3}{ }^{-}, \mathrm{SO}_{4}{ }^{2-}, \mathrm{Ca}^{2+}$, and $\mathrm{Mg}^{2+}$ (Olichwer et al., 2013; Olichwer and Tarka, 2018).

To sum up, the thermal waters with low mineralization are mainly multi-ion and the bicarbonate-chloride-sodium-calcium type is dominant. The thermo-mineral waters, on the other hand, primarily belong to the chloride-sodium and chloride- bicarbonate-sodium types (Table 1).

Based on the variations in the physicochemical characteristics, two types of thermal waters are distinguished in the study area. The first type is associated with the thermal waters originating from deep circulation waters in metamorphic rocks (Hornsund and Raudfjellet). The other type is related to the thermal waters originating from a mixture of subpermafrost hot brines and glacial waters (Sörkappland) (Olichwer and Tarka, 2018).

\section{Methods}

In this study, a chemical geothermometer, based on the relationship between silica solubility and temperature, was used to determine temperatures in the groundwater reservoirs of southern Spitsbergen. Moreover, a number of chemical geothermometers based on the ratios of the cations contained in the thermal water, i.e. Na-K, Na-K-Mg, $\mathrm{Na}-\mathrm{K}-\mathrm{Ca}$, Na-Li, Mg-Li, K-Mg, and Ca-Mg, were employed, and finally the $\delta^{18} \mathrm{O}$ isotopic geothermometer in the $\mathrm{SO}_{4}-\mathrm{H}_{2} \mathrm{O}$ system (Table 2).

The results of chemical and isotopic analyses of the thermal springs obtained during scientific expeditions in the period 2006-2011 (Table 3 ) and published in several articles (Olichwer et al., 2013; Olichwer and Tarka, 2018; Szynkiewicz et al., 2020) were used to characterize the depth of thermal water circulation using geothermometers. Furthermore, the above-mentioned papers contain a detailed analysis of the physicochemical and isotopic composition of the thermal waters described.

Due to the low silica concentrations (several $\mathrm{mg} / \mathrm{dm}^{3}$ ) in the thermal springs of southern Spitsbergen, which resulted from the mixing of deep thermal waters with cold shallow circulation waters, it was not possible to obtain reliable results using the silica geothermometer. Therefore, it was necessary to apply the water mixing model according to Fournier and Truesdell (1974) which allows determining the original silica content in thermal water before it is diluted by cold water. The derived value of the silica content in the thermal water was used in the silica geothermometer calculations. This mixing model can be used for springs with temperatures below $100^{\circ} \mathrm{C}$ (Fournier and Truesdell, 1974). The input data are the silica and enthalpy values for the thermal spring and for the diluting cold water (shallow circulation). In the model, the enthalpy of the hot water and steam that mixes with the cold water and heats it is the same as the initial enthalpy of the deep hot water. The condition is that the initial silica content in the deep thermal water is controlled by quartz solubility. This model applies the plot of relationship between dissolved silica and enthalpy (Truesdell and Fournier, 1977) (Fig. 2).

In the situation where the steam is not lost before mixing, the silica content and the enthalpy of the cold and warm water are plotted as two points, A and B, and a straight line is drawn, which goes through these points to the point of intersection with the quartz solubility curve. Point $\mathrm{C}$ indicates the original silica content at the bottom of the thermal water reservoir and the enthalpy of this water (Fig. 2). The silica value so derived can be subsequently used in silica geothermometers. The above water mixing model uses the silica value $\left(0.6 \mathrm{mg} / \mathrm{dm}^{3}\right)$ and the cold water temperature $\left(2.5^{\circ} \mathrm{C}\right)$, corresponding to the shallow circulation waters originating from permafrost melting (Olichwer et al., 2013). Due to the similar temperatures and silica contents in the thermal springs, approximation was done by plotting a common line for all the sites, which allowed point $\mathrm{C}$ to be determined. In this way, the original silica content was estimated, i.e. $30 \mathrm{mg} / \mathrm{kg}$, which was the average value characterizing all the sites.

A general flowchart showed the research methodology is presented below in the Fig. 3.

\section{Results}

The silica geothermometer is a chemical geothermometer that has been commonly used for a long time. Fournier (1977) recommends this geothermometer as being particularly appropriate to most lowtemperature thermal systems. As mentioned before, thanks to the water mixing model according to Fournier and Truesdell (1974), the original silica content $(30 \mathrm{mg} / \mathrm{kg})$ in the hot water was determined, which allowed this geothermometer to be applied. In the case of the thermal waters found in the study area, reservoir water temperatures ranging $50-80^{\circ} \mathrm{C}$ were obtained (Table 4). The silica geothermometer was used too for thermal waters in northern Spitsbergen where higher temperatures of reservoir waters were obtained (ranging $70-150^{\circ} \mathrm{C}$ ) (Banks et al., 1998).

Among geothermometers based on cation ratios, the Na-K geothermometer (not susceptible to dilution) suggests that the thermal waters in the study area come from hot waters with an initial temperature in the range of $100-190^{\circ} \mathrm{C}$. An exception is the Bjørnbein spring in which a 
Table 2. Temperature equations for geothermometers

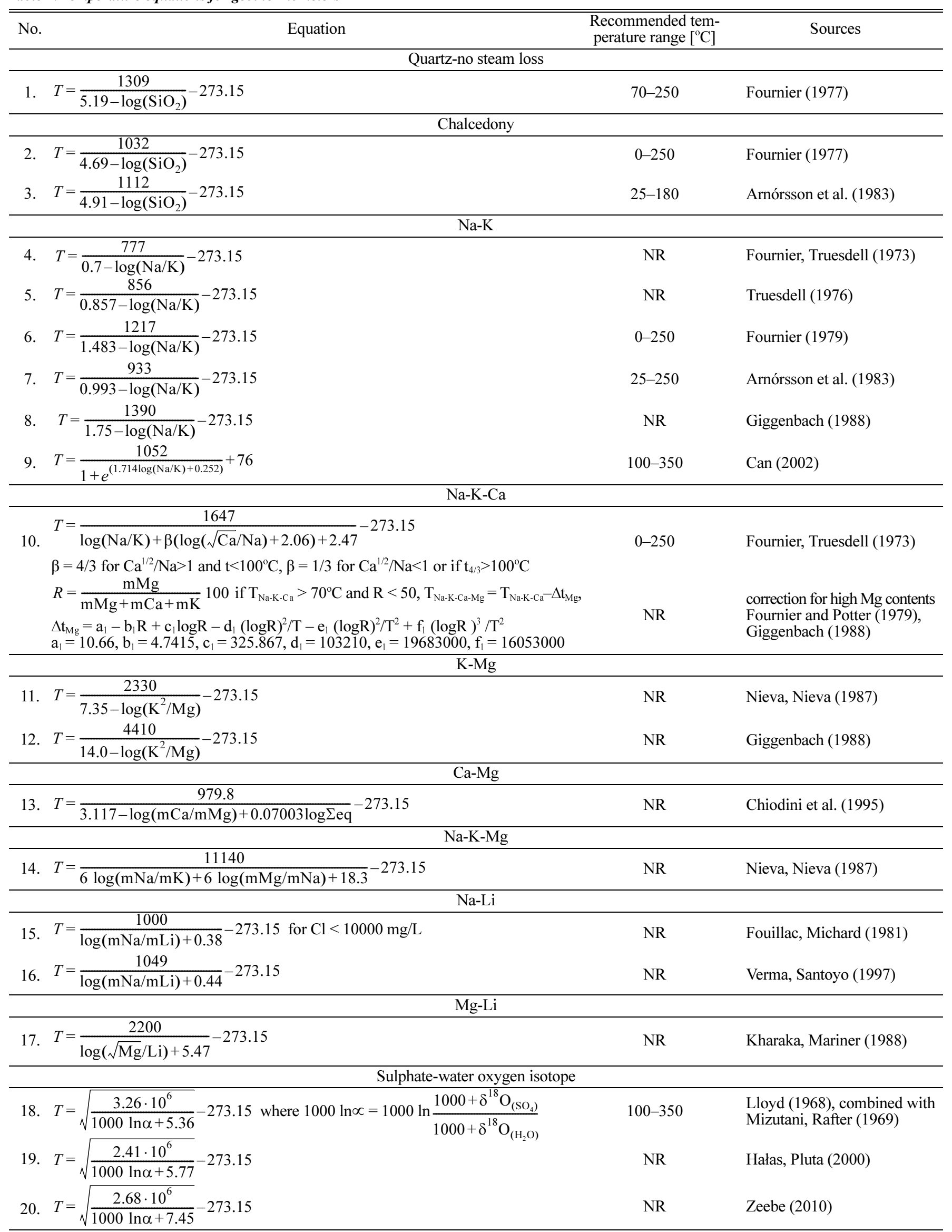

$\mathrm{T}-{ }^{\circ} \mathrm{C}$, ion concentration: $\mathrm{SiO}_{2}, \mathrm{Na}$ and others - in $\mathrm{mg} / \mathrm{dm}^{3}, \mathrm{mNa}$ - in molality, [K] - in equivalents (Molality/Charge). 
Table 3. Chemical data included in geothermometers

\begin{tabular}{|c|c|c|c|c|c|c|c|c|c|c|c|}
\hline Spring & $\overline{\mathrm{T}}$ & $\overline{\mathrm{pH}}$ & $\overline{\mathrm{TDS}}$ & $\overline{\mathrm{SiO}} \mathrm{SiO}_{2}$ & $\overline{\mathrm{Ca}}$ & $\overline{\mathrm{Mg}}$ & $\mathrm{Na}$ & $\overline{\mathrm{K}}$ & $\overline{\mathrm{Li}}$ & $\overline{\delta^{18} \mathrm{O}}$ & $\overline{\delta^{18} \mathrm{O}\left(\mathrm{SO}_{4}\right)}$ \\
\hline & {$\left[{ }^{\circ} \mathrm{C}\right]$} & & \multicolumn{7}{|c|}{$\left[\mathrm{mg} / \mathrm{dm}^{3}\right]$} & \multicolumn{2}{|c|}{$[\% 0]$} \\
\hline Raud & 11.9 & 8.03 & 228.3 & 1.430 & 17.14 & 10.15 & 35.75 & 2.17 & 0.0110 & -10.7 & -1.3 \\
\hline Olsok & 9.3 & 6.96 & 4031.4 & 1.570 & 173.3 & 36.53 & 1260.7 & 53.2 & 1.2010 & -10.3 & +2.7 \\
\hline Bjørnbein & 13.9 & 8.41 & 346.6 & 1.840 & 40.42 & 10.08 & 43.33 & 5.07 & 0.0410 & -7.9 & -4.2 \\
\hline Orvin & 13.0 & 7.51 & 378.2 & 3.28 & 29.91 & 16.13 & 64.25 & 2.87 & 0.0190 & -10.8 & +1.3 \\
\hline Trollosen & 3.4 & 7.43 & 1638.1 & 1.68 & 79.43 & 12.23 & 501.5 & 20.64 & 0.444 & -11.0 & n.a. \\
\hline
\end{tabular}

n.a. - not analyzed

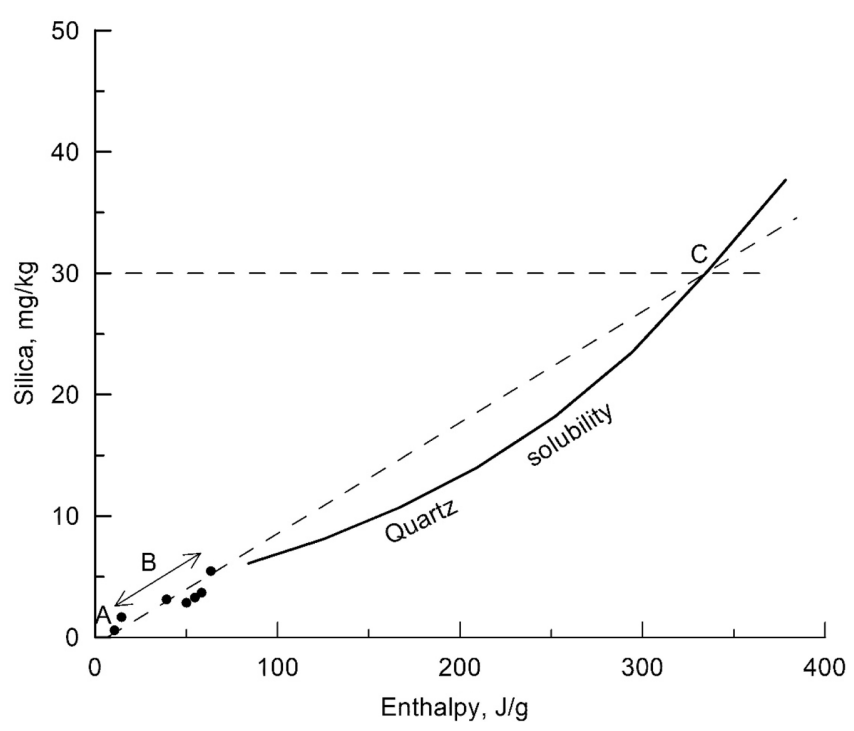

Figure 2. Silica-enthalpy mixing model for southern Spitsbergen thermal springs.

temperature ranging $200-240^{\circ} \mathrm{C}$ was recorded. The values derived using the Giggenbach $\mathrm{Na} / \mathrm{K}$ geothermometer (1988) are higher by about 20$30^{\circ} \mathrm{C}$ than for the other $\mathrm{Na} / \mathrm{K}$ geothermometers applied (Table 4).

A more comprehensive Na-K-Ca thermometer (Fournier and Truesdell, 1973) indicates temperatures ranging $45-150^{\circ} \mathrm{C}$ (Table 4).
There are two formulas for Na-K-Ca geothermometers, depending on the reservoir water temperature. The first one is for waters with a temperature below $100^{\circ} \mathrm{C}$, where the value of $\beta=4 / 3$, while the other one for waters above $100^{\circ} \mathrm{C}$, where $\beta=1 / 3$. In the case of reservoir water temperatures around $100^{\circ} \mathrm{C}$, the calculations made using this geothermometer are ambiguous due to the fact that it is possible to accept any of these coefficients. However taking into account the adjustment for the magnesium content (Fournier and Potter, 1979) and using the formula, where $\beta=4 / 3$, temperatures in the range of $45-89^{\circ} \mathrm{C}$ were obtained (Table 4 ). Due to the low-temperature environment of thermal waters of the study area, it is reasonable to choose such a solution.

In the case of the $\mathrm{Na}-\mathrm{K}-\mathrm{Mg}$ and $\mathrm{K}-\mathrm{Mg}$ geothermometers (Nieva and Nieva, 1987; Giggenbach, 1988), a large scatter of the results can be observed, from 30 to $185^{\circ} \mathrm{C}$ (Table 4). As regards the other chemical geothermometers based on cation ratios, such as $\mathrm{Mg}-\mathrm{Li}$, Na-Li and $\mathrm{Ca}-\mathrm{Mg}$, temperatures below $100^{\circ} \mathrm{C}$ are dominant.

Application of the $\delta^{18} \mathrm{O}$ isotopic geothermometer in the $\mathrm{SO}_{4}-\mathrm{H}_{2} \mathrm{O}$ system, depending on the selected isotopic fractionation factor (Lloyd, 1968; Mizutani and Rafter, 1969; Zeebe, 2010), gives in most cases temperature values from about 85 to $190^{\circ} \mathrm{C}$. Again, an exception is the Bjornbein spring where a temperature ranging $220-320^{\circ} \mathrm{C}$ was recorded. The highest values of temperature were obtained, using the combined geothermometers of Lloyd (1968) and Mizutani and Rafter (1969) $\left(143-312^{\circ} \mathrm{C}\right)$. Lower temperatures were calculated for the oxygen isotope fractionation factors in the $\mathrm{SO}_{4}-\mathrm{H}_{2} \mathrm{O}$ system reported by Hałas and Pluta $(2000)\left(93-231^{\circ} \mathrm{C}\right)$ and Zeebe $(2010)\left(88-217^{\circ} \mathrm{C}\right)$.

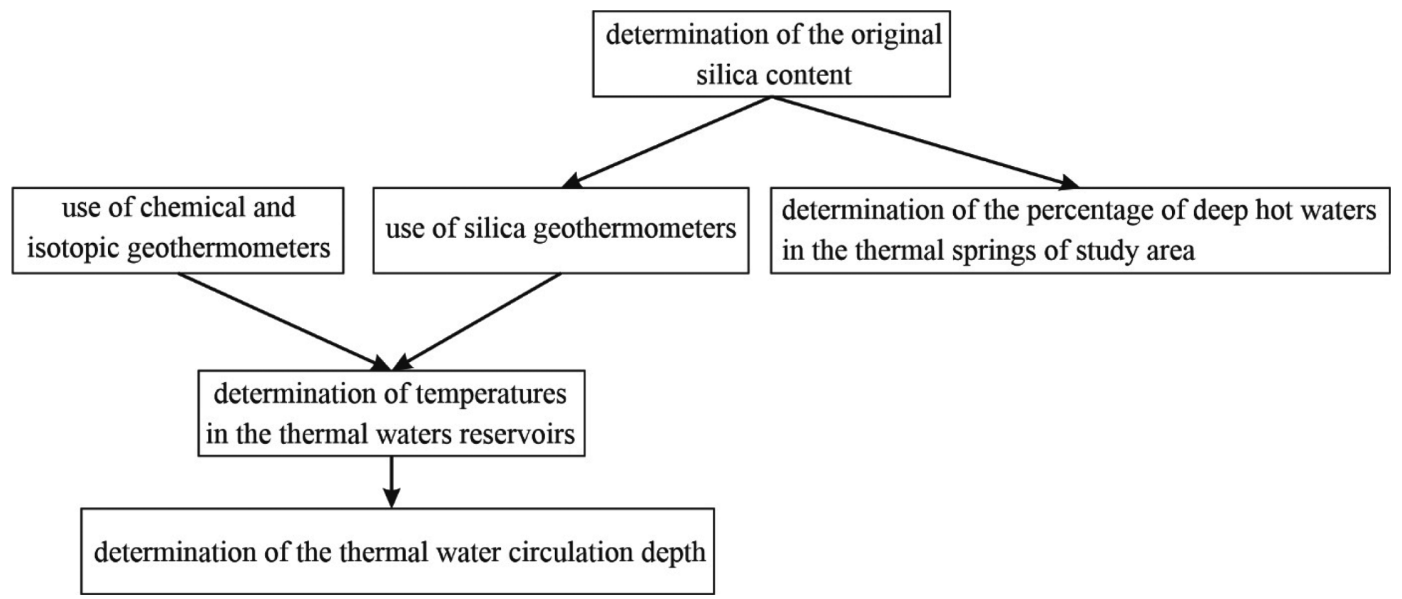

Figure 3. Research methodology. 
Table 4. Temperatures $(C)$ calculated by the application of common geothermometers to sampled waters in southern Spitsbergen thermal springs

\begin{tabular}{|c|c|c|c|c|c|c|}
\hline & \multicolumn{6}{|c|}{ Spring } \\
\hline & Olsok & Bjørnbein & Fisosen & Trollosen & Orvin & Raud \\
\hline \multicolumn{7}{|c|}{ Quartz - no steam loss and chalcedony } \\
\hline Fournier (1973) & \multicolumn{6}{|c|}{79} \\
\hline Fournier (1977) & \multicolumn{6}{|c|}{48} \\
\hline Arnórsson et al. (1983) & \multicolumn{6}{|c|}{51} \\
\hline \multicolumn{7}{|c|}{$\mathrm{Na}-\mathrm{K}$} \\
\hline Fournier and Truesdell (1973) & 101 & 203 & 99 & 99 & 106 & 132 \\
\hline Truesdell (1976) & 110 & 205 & 108 & 109 & 115 & 140 \\
\hline Fournier (1979) & 153 & 231 & 151 & 151 & 156 & 178 \\
\hline Arnorsson et al. (1983) & 121 & 212 & 119 & 119 & 125 & 149 \\
\hline Giggenbach (1988) & 172 & 245 & 170 & 170 & 175 & 195 \\
\hline Can (2002) & 148 & 219 & 147 & 147 & 151 & 169 \\
\hline \multicolumn{7}{|c|}{$\mathrm{Na}-\mathrm{K}-\mathrm{Ca}$} \\
\hline Fournier and Truesdell (1973) $-\beta=1 / 3$ & 152 & 159 & 150 & 143 & 124 & 132 \\
\hline Fournier and Truesdell (1973) $-\beta=4 / 3$ & 144 & 54 & 137 & 113 & 47 & 45 \\
\hline T corr. for Mg content Fournier and Potter (1979), Giggenbach (1988) & 73 & - & 61 & 89 & - & - \\
\hline \multicolumn{7}{|c|}{$\mathrm{K}-\mathrm{Mg}$} \\
\hline Nieva and Nieva (1987) & 154 & 52 & 138 & 128 & 32 & 30 \\
\hline Giggenbach (1988) & 91 & 51 & 85 & 81 & 35 & 35 \\
\hline \multicolumn{7}{|l|}{$\mathrm{Ca}-\mathrm{Mg}$} \\
\hline Chiodini et al. (1995) & 79 & 79 & 67 & 100 & 41 & 39 \\
\hline \multicolumn{7}{|c|}{$\mathrm{Na}-\mathrm{K}-\mathrm{Mg}$} \\
\hline Nieva and Nieva (1987) & 179 & 185 & 175 & 172 & 144 & 152 \\
\hline \multicolumn{7}{|l|}{$\mathrm{Na}-\mathrm{Li}$} \\
\hline Fouillac and Michard (1981) & 74 & 74 & 79 & 70 & 22 & 23 \\
\hline Verma and Santoyo (1997) & 84 & 83 & 89 & 80 & 31 & 33 \\
\hline \multicolumn{7}{|c|}{ Mg-Li } \\
\hline Kharaka and Mariner (1988) & 83 & 26 & 80 & 72 & (9) & (4) \\
\hline \multicolumn{7}{|c|}{ isotopic geotermometer $\delta^{18} \mathrm{O}$ in the system $\mathrm{SO}_{4}-\mathrm{H}_{2} \mathrm{O}$} \\
\hline Lloyd (1968), Mizutani and Rafter (1969) & 143 & 312 & - & - & 153 & 189 \\
\hline Hałas and Pluta (2000) & 85 & 231 & - & - & 93 & 125 \\
\hline Zeebe (2010) & 88 & 217 & - & - & 97 & 125 \\
\hline
\end{tabular}

\section{Discussion}

The analysis of the study results for the thermal springs of southern Spitsbergen using a number of different geothermometers provides ambiguous information on the temperatures in the groundwater reservoirs. The specificity of the investigated thermal waters in the study area, i.e. their low enthalpy and low water silica content at the outflow, suggests that during ascent the original thermal waters mix with cold shallow circulation waters. Due to this, not all geothermometers give actual values of the original water temperature in the groundwater reservoir. Therefore, it is necessary to comprehensively analyze the derived results using a range of different geothermometers and an indication of geothermometers that best reflect the geothermal conditions of southern Spitsbergen.

In the case of silica geothermometers, we obtain reliable values not for all types of thermal water. For example, waters with a low $\mathrm{pH}$ and a high content of $\mathrm{CO}_{2}$ dissolve silicates quite quickly and then equilibrium between the hydrated silica and secondarily precipitated quartz or chalcedony is impossible for kinetic reasons (D'Amore and Arnórsson, 2000). Application of silica geothermometers is also inappropriate in the case of highly mineralized waters (mineralization higher than the average one for seawater) since it results in significant errors in water temperature estimation (Porowski, 2007). In the study area, the chloride content in thermal waters does not exceed $2,145 \mathrm{mg} / \mathrm{dm}^{3}$ (Olichwer et al., 2013; Olichwer and Tarka, 2018), which allows the silica geothermometer to be used. Furthermore, it is important that during ascent thermal water should not be significantly diluted by shallow circulation waters originating from permafrost or glacier melting. The original silica content $(30 \mathrm{mg} / \mathrm{kg})$ in the hot water (Fig. 2), estimated by authors using the Fournier and Truesdell mixing model (1974), indicates that in the thermal water outflows of southern Spitsbergen the percentage of cold shallow circulation waters is about $85 \%$, while the percentage of deep circulation thermal waters is $15 \%$. In turn, the 


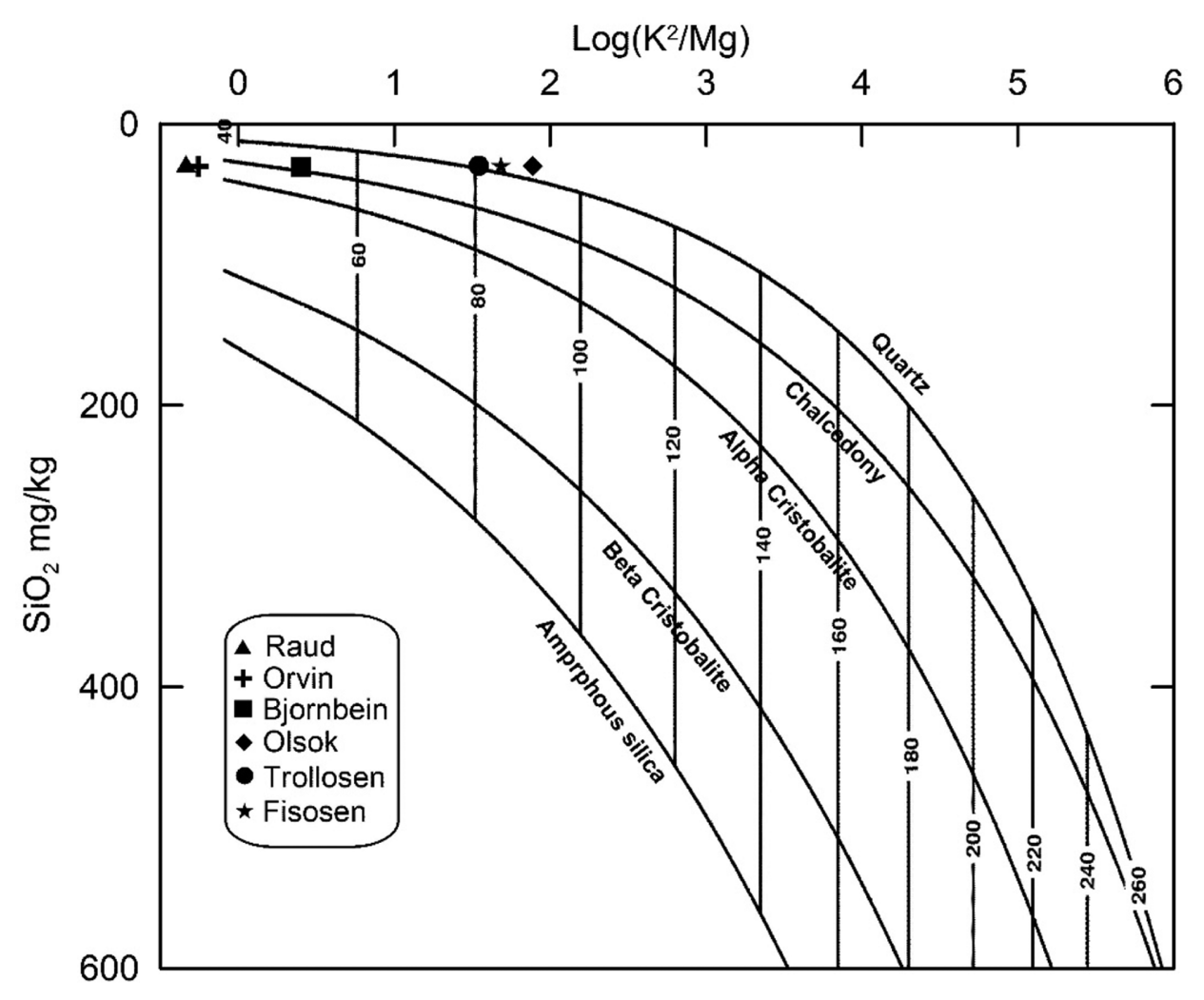

Figure 4. Cross-plot of K-Mg geothermometer versus silica contents for southern Spitsbergen thermal springs.

study of thermal waters in northern Spitsbergen (Banks et al., 1998) demonstrates a $10-30 \%$ proportion of thermal water diluted by $70-90 \%$ cold water. The lower percentage of hot waters in the thermal springs of study area, relative to those in the northern part of Spitsbergen, is confirmed by the lower silica concentrations in the springs (10-fold lower contents) and the twice lower water outflow temperature of the the Hornsund fjord area, Raudfjellet massif and the Sörkappland area.

Obtaining one value of the original silica content for all the springs prevents wider interpretation of the results acquired using this geothermometer. However, a comparison of this value with the $\mathrm{K}-\mathrm{Mg}$ geothermometer in a cross-plot (Fig. 4) indicates two groups of springs differing in their reservoir water temperature. The Olsok, Trollosen, and Fisosen springs show saturation relative to quartz at reservoir temperatures of $80-90^{\circ} \mathrm{C}$. The Bjørnbein, Orvin, and Raud springs, in turn, exhibit saturation relative to chalcedony at reservoir temperatures of $30-50^{\circ} \mathrm{C}$. The first group of springs with higher reservoir temperatures are mineral waters, influenced by inflows of hot brines from sedimentary rocks. The second group consists of springs with outflows of low mineralized thermal water, circulating in carbonate crystalline rocks.

Among cation geothermometers, the most popular one is the Na-K type. It produces the best results in the case of waters originating from a thermal environment above $180^{\circ} \mathrm{C}$, containing little calcium. The advantage is that the cation geothermometer is less susceptible to dilution, assuming that the diluting water has a low sodium and potassium content (Ellis and Mahon, 1967; Fournier and Truesdell, 1973; Fournier, 1979). Moreover, it is thought that it takes more time to balance $\mathrm{Na}^{+}$and $\mathrm{K}^{+}$again than in the case of the components used in other geothermometers, and hence this method can be employed to estimate the highest temperatures in the deeper parts of a geothermal system where the waters have remained for a relatively long time. At lower temperatures, the ion exchange between the waters complicate the use of Na-K geothermometers, leading to large differences in temperatures calculated using different formulas (D'Amore and Arnórsson, 2000), as in the case of the thermal waters of the research area.

The basic assumption for the applicability of cation geothermometers, including $\mathrm{Na}-\mathrm{K}$, is to reach chemical equilibrium between the water and the rock. To assess the achievement of equilibrium, the ternary Na-K-Mg diagram according to Giggenbach (1988) was applied by authors. This diagram divides water into three groups: (I) fully equilibrated water (mature); (II) partially equilibrated water (mixed water); and (III) immature waters (Fig. 5). When analyzing Fig. 5, it can be noticed that the Olsok, Trollosen, and Fisosen sites are in the water field no. 2. In turn, the Bjorbein, Orvin, and Raud springs are located near the $\mathrm{Mg}$ corner, in the area of immature waters, which indicates that these thermal waters are not suitable for Na-K geothermometers. Thus, this geothermometer is only partially useful for thermomineral waters circulating in the sedimentary rocks of the Sörkappland area.

Based on the authors' analyzes, under the hydrogeochemical conditions of the study area (low enthalpy), it seems that out of 6 the Na$\mathrm{K}$ geothermometers applied, the Na-K geothermometers according to Truesdell (1976) and Fournier and Truesdell (1973) are particularly appropriate to most low-temperature thermal systems and give the most objective results. Using the above-mentioned geothermometers the temperatures of about $100-110^{\circ} \mathrm{C}$ were calculated for the thermal 


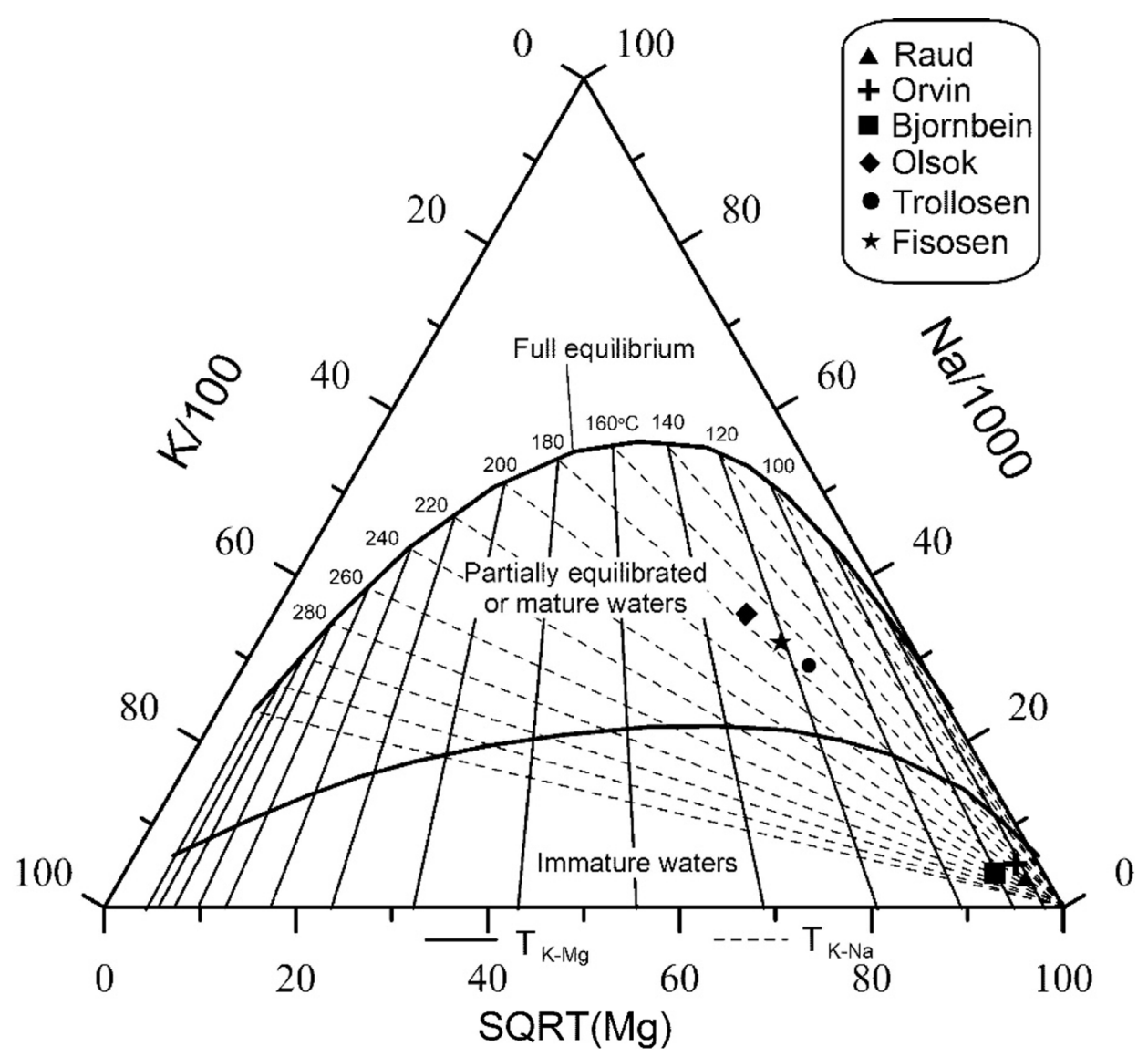

Figure 5. Na-K-Mg ternary diagram (Giggenbach 1988) for southern Spitsbergen thermal springs.

springs (Olsok, Trollosen i Fisosen) showing partial equilibrium (Fig. 5). Higher temperatures, in the range of $170^{\circ} \mathrm{C}$, were obtained by the $\mathrm{Na}-\mathrm{K}-\mathrm{Mg}$ geothermometer and also in the case of the other $\mathrm{Na}-\mathrm{K}$ geothermometers employed. In these cases, the calculated temperatures are much higher than those estimated by the silica geothermometer.

The Na-K-Ca geothermometer (Fournier and Truesdell, 1973) is a chemical geothermometer used too in low temperature hydrogeological systems. This geothermometer has application for a wider range of thermal fluids than the Na-K geothermometer. A drawback of the Na$\mathrm{K}-\mathrm{Ca}$ geothermometer is its susceptibility to dilution, especially if the percentage of the original thermal water in the mixture is below $30 \%$ (Fournier and Truesdell, 1973). We deal with such a situation in southern Spitsbergen, where according to the authors the percentage of deep circulation waters in the thermal springs is about $15 \%$. Notwithstanding the above limitations, using the formula with $\beta=4 / 3$, temperatures in the range of $45-89^{\circ} \mathrm{C}$ were obtained, suggesting low-temperature hydrogeological systems of thermal waters in the study area.

Additionally in the case of the thermal waters of southern Spitsbergen, the Na-K-Ca geothermometer confirms the results derived using the silica and $\mathrm{K}-\mathrm{Mg}$ geothermometers. So these 3 geothermometers are showing two groups of results, which confirm the existence of two types of hot water reservoirs in the study area. The first one, probably a shallower reservoir, is related to the Bjørnbein, Orvin, and Raud sites $\left(35-54^{\circ} \mathrm{C}\right)$. The other one, a deeper reservoir, is associated with the Olsok, Trollosen, and Fisosen sites $\left(61-91^{\circ} \mathrm{C}\right)$.
Other geothermometers applied for thermal waters with not high temperatures are the $\mathrm{Mg}-\mathrm{Li}$ and $\mathrm{Ca}-\mathrm{Mg}$ geothermometers (Kharak and Mariner, 1989; Chiodini et al., 1995). These geothermometers are based on faster $\mathrm{Mg}$ cation exchange reactions at lower temperatures and they provide reliable temperature estimates, but for the last waterrock equilibrium temperature (Giggenbach, 1988). When these geothermometers were used, temperature values ranging $40-100^{\circ} \mathrm{C}$ were obtained. In this case, a dichotomy in the derived results can also be seen. Lower temperature estimates were obtained for the Bjørnbein, Orvin, and Raud sites, in the range of $40-80^{\circ} \mathrm{C}(\mathrm{Ca}-\mathrm{Mg}$ geothermometer), while for the Olsok, Trollosen, and Fisosen sites the temperatures were within the range of $67-100^{\circ} \mathrm{C}$. The $\mathrm{Mg}$ - Li geothermometer did not allow reliable results to be achieved in the case of the Orvin and Raud sites where the calculated reservoir water temperatures are lower than for the discharged waters. The temperature estimated by this geothermometer for the Bjørnbein site also seems to be underestimated.

In the case of the Na-Li geothermometer, the calculated temperatures $\left(22-89^{\circ} \mathrm{C}\right)$ prevailing in the groundwater reservoir correspond to the results obtained using the $\mathrm{Mg}-\mathrm{Li}$ and $\mathrm{Ca}-\mathrm{Mg}$ geothermometers. This once again confirms the low-temperature environment of the origin of the thermal waters in southern Spitsbergen.

Among isotopic geothermometers, the $\delta^{18} \mathrm{O}$ isotopic geothermometer in the $\mathrm{SO}_{4}-\mathrm{H}_{2} \mathrm{O}$ system is the most popular one. It uses the fact that the oxygen isotope fractionation factor between the water and sul- 
fates dissolved in it is the function of water temperature and $\mathrm{pH}$ (Mizutani and Rafter, 1969). Many oxygen isotope fractionation factors in the $\mathrm{SO}_{4}-\mathrm{H}_{2} \mathrm{O}$ system are used in the literature (Loyd, 1968; Mizutani and Rafter, 1969; Kusakabe and Robinson, 1977). The rate of oxygen isotopic exchange between water and sulfates in acidic and neutral environments at temperatures above $100^{\circ} \mathrm{C}$ is quite fast (several-several dozen years), whereas it is much slower at temperatures below $100^{\circ} \mathrm{C}$ (about 500 years) (Lloyd, 1968; Porowski, 2007). In some deep aquifers, the water residence time in the system can be long enough for the oxygen isotopic equilibrium in the $\mathrm{SO}_{4}-\mathrm{H}_{2} \mathrm{O}$ system to be reached at temperatures lower than $100^{\circ} \mathrm{C}$ (Fouillac et al., 1990). A drawback of this geothermometer is that the sulfate content in thermal waters can be influenced by, e.g., bacterial sulfate reduction, mixing of waters of different origin, or evaporation, which disturbs isotopic equilibrium conditions. In such a situation, the isotopic signature does not reflect $100 \%$ of the signature of deep geothermal sulfate (Fouillac et al., 1990).

The isotopic exchange of oxygen in the $\mathrm{SO}_{4}-\mathrm{H}_{2} \mathrm{O}$ system occurs through the participation of $\mathrm{H}_{4} \mathrm{SiO}_{2}$ and $\mathrm{H}_{2} \mathrm{O}$ molecules when the $\mathrm{pH}$ is acidic or with the participation of $\mathrm{HSO}_{4}{ }^{-}$and $\mathrm{H}_{2} \mathrm{O}$ when it is neutral (Chiba and Sakai, 1985). Because the thermal waters of the study area have a $\mathrm{pH}$ close to neutral (Table 3), sulfates dissolved in the water must therefore occur as a mixture of $\mathrm{SO}_{4}{ }^{2-}$ and $\mathrm{HSO}_{4}^{-}$. In this situation, the temperature scale should be between the isotopic exchange for $\mathrm{HSO}_{4}$ (according to Mizutani and Rafter, 1969) and for $\mathrm{SO}_{4}{ }^{2-}$ (according to Lloyd, 1968). This demonstrates that we obtain the most probable results for the thermal waters of southern Spitsbergen by applying the combined geothermometers of Lloyd (1968) and Mizutani and Rafter (1969). Nonetheless, the obtained water temperatures in deep reservoirs (143$312^{\circ} \mathrm{C}$ ) correspond only to the Na-K geothermometer, which produced higher temperatures estimates than the other geothermometers. Lower temperatures were calculated for the oxygen isotope fractionation factors in the $\mathrm{SO}_{4}-\mathrm{H}_{2} \mathrm{O}$ system reported by Hałas and Pluta (2000) $\left(93-231^{\circ} \mathrm{C}\right)$ and Zeebe $(2010)\left(88-217^{\circ} \mathrm{C}\right)$. However, they do not correspond to the temperatures obtained using chemical geothermometers, which are more predisposed to use in low enthalpy conditions. Thus, due to the very large discrepancies in the results, the use of an isotope geothermometer is loaded a large error.

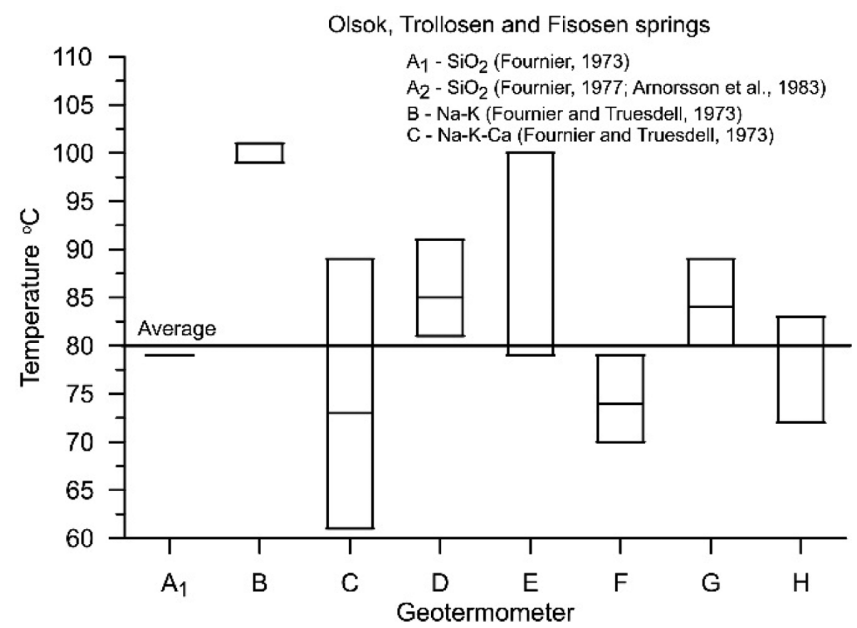

\section{Estimation of the Thermal Water Circulation Depth}

The determination of reservoir water temperatures by authors using the geothermometers allowed the depth of thermal water circulation in southern Spitsbergen to be estimated. The geothermal studies conducted in the central and southern parts of Spitsbergen indicate a heat flow value of about $70 \mathrm{~mW} / \mathrm{m}^{2}$ and a geothermal gradient of $3.5^{\circ} \mathrm{C} /$ $100 \mathrm{~m}$ (Braathen et al., 2012; Wawrzyniak et al., 2016). These values are lower than those found in the north of Spitsbergen where the thermal springs at the Bockfjorden site are located within a geothermal anomaly area. The heat flow values determined there are about 130 $\mathrm{mW} / \mathrm{m}^{2}$ (Vagnes and Amundsen, 1993). Furthermore, the xenolithic evidence originating from Quaternary volcanism at Bockfjorden suggests temperatures of $550^{\circ} \mathrm{C}$ at a depth of $7 \mathrm{~km}$ (Amundsen et al., 1987), which corresponds to an average temperature gradient of about $0.079^{\circ} \mathrm{C} / \mathrm{m}$ and a thermal water circulation depth of $1.6-2.3 \mathrm{~km}$ in this area (Banks et al., 1998).

As mentioned earlier in the article, most of the geothermometers used show two groups of results, which suggests the existence of two types of hot water reservoirs in the study area. As far as the Olsok, Trollosen, and Fisosen springs with increased mineralization are concerned, the derived hot water reservoir temperatures were at a level of $80^{\circ} \mathrm{C}$ on average (Fig. 6), which gives a thermal water circulation depth of $2.3 \mathrm{~km}$ with an assumed geothermal gradient of $3.5^{\circ} \mathrm{C} / 100 \mathrm{~m}$. This corresponds to the depth ranges of occurrence of Carboniferous-Triassic sedimentary rocks with evaporite interbeds, which are responsible for inflows of hot brines.

At the Bjørnbein, Orvin, and Raud sites, in turn, lower temperatures are recorded, on average $40^{\circ} \mathrm{C}$ (Fig. 6), which gives a thermal water circulation depth of about $1.1 \mathrm{~km}$. The Orvin and Raud springs, located in the Hornsund fjord area and at the foot of Raudfjellet, are geologically related to early Paleozoic crystalline carbonate rocks of the Hecla Hoek succession. Thus, the circulation of thermal waters is associated with the tectonic zones found there and rock mass fractures. Bjørnbein is a unique spring because, in spite of the close location of the Olsok, Trollosen, and Fisosen sites, it has different characteris-

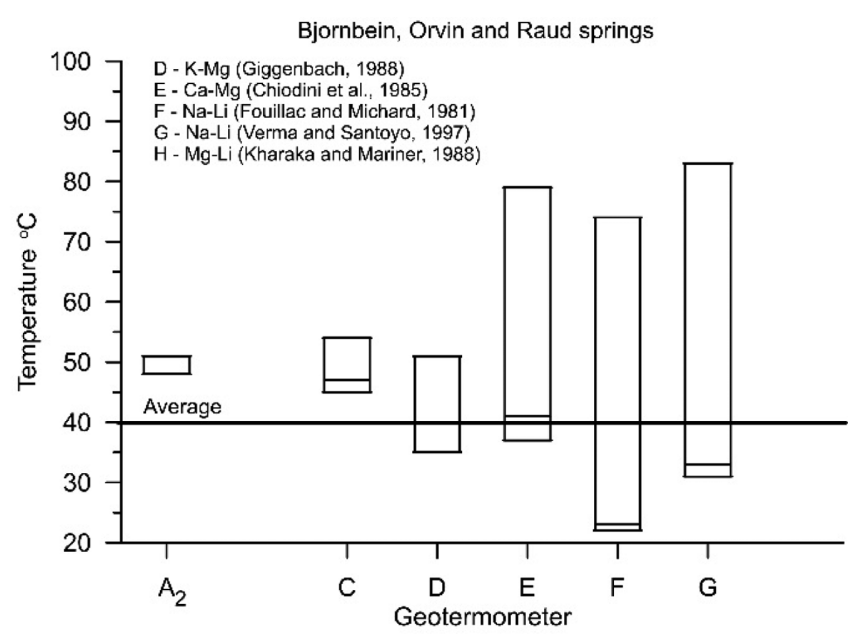

Figure 6. Temperature ranges in the thermal water reservoirs of the research area. 
tics than these springs. In the first place, it has much lower mineralization, a different hydrochemical type of water, and shallower circulation pathways. These features suggest that this spring discharges waters circulating in the tectonic zones without the inflow of hot brines. Therefore, if there is any brine inflow to the thermal water reservoirs of Olsok, Trollosen and Fisosen springs, it must come from depths greater than $1.1 \mathrm{~km}$.

\section{Conclusion}

The thermal springs of Spitsbergen have been the subject of research by hydrogeologists for many years. By studying the thermal springs, it is possible to describe the deep circulation of water below the permafrost. Circulation depths of groundwater can reach over $2 \mathrm{~km}$, which is confirmed by studies in northern Spitsbergen.

In comparison to the whole island, deep thermal water reservoirs are the least recognized in the southern part. First of all, there is a lack of more knowledge about the depths to which water from glaciers and melting permafrost infiltrates. There is no information about the temperatures in the reservoirs of thermal water, which escape to the land surface through tectonic discontinuities. Also, little is known to what extent hot waters from deep reservoirs are diluted by shallow circulating cold waters.

To assess the circulation depth of thermal waters in southern Spitsbergen and a more complete characterization of hot water reservoirs several well-known chemical and isotopic geothermometers were used, which are in particular suitable for systems under low temperature conditions.

Based on the study of the thermal springs in the study area using these geothermometers, ambiguous information was obtained with regard to the temperatures prevailing inside the groundwater reservoirs. However, the dominant values derived based on the geothermometers indicate temperatures in the range of several dozen degrees Celsius, but it possible to overestimate the actual temperatures in the thermal water reservoirs. Interpretation of the geothermometer data should be cautious because in such a case many factors affect the water discharged to the ground surface. The study area is characterized by a very diverse land surface and high geological variability. The groundwater circulates slowly and long distances; due to this, the water circulating in a rock environment can be impacted by many factors, for example the loss of heat during the ascent of the thermal water. The ascent through colder rocks and contact with young cold waters cools it down, causing the chemical composition to be modified and then new equilibrium states can be created. In such case, the outflow temperature suggests the last equilibrium state and not the one from the deeper parts where the water circulated previously (Fournier, 1977). In addition, the temperature indicated by geothermometers is not necessarily the maximum water temperature in the aquifer, but the temperature at which the components of the minerals making up the rocks of the reservoir which are dissolved in the water are in chemical equilibrium with such minerals. Taking account for certain imperfections in the applied methodology, it can however be stated that the application of comprehensive solutions such as the simultaneous use of a number of different geothermometers, supported by the mixing models, allows us to obtain temperatures of groundwa- ter reservoirs for low enthalpy waters. The use of single geothermometers can cause the temperatures in such reservoirs to be underestimated or overestimated.

The conducted calculations of reservoir water temperatures for the thermal outflows in southern Spitsbergen using a range of geothermometers showed that the most homogeneous temperature range (predominant range $40-80^{\circ} \mathrm{C}$ ) was obtained for the $\mathrm{Na}-\mathrm{K}-\mathrm{Ca}, \mathrm{K}-\mathrm{Mg}$, $\mathrm{Ca}-\mathrm{Mg}$, and $\mathrm{Na}-\mathrm{Li}$ geothermometers as well as for the silica geothermometer using the mixing model that allows the original silica content to be determined. The above geothermometers are best suited for low enthalpy waters found in polar areas, which are not of volcanic origin.

In addition, the commonly used $\mathrm{Na}-\mathrm{K}$ geothermometer gives results consistent with the above-mentioned geothermometers only in the case of mature or partially mature waters, represented by thermo-mineral waters from the Sørkappland area. The versions of this geothermometer according to Fournier and Truesdell (1973) and Truesdell (1976) are the most suitable for the springs analyzed. In turn, higher temperature values $\left(120-245^{\circ} \mathrm{C}\right)$ are obtained by using the Na-K geothermometers according to Fournier (1979), Arnórsson et al. (1983), Giggenbach (1988), or Can (2002).

High temperatures $\left(140-180^{\circ} \mathrm{C}\right)$ were also derived based on the NaK-Ca geothermometer according to Nieva and Nieva (1987). In these cases, the calculated temperatures seem to be overestimated relative to the actual reservoir water temperatures, this is especially true for the Orvin, Raud and Bjørnbein sites (low-mineralized waters).

As far as the $\delta^{18} \mathrm{O}$ isotopic geothermometer in the $\mathrm{SO}_{4}-\mathrm{H}_{2} \mathrm{O}$ system is concerned, ambiguous temperatures with a wide range of values were generated, which prevented their interpretation. Uncertain values were also obtained by the $\mathrm{Na}-\mathrm{K}$ and $\mathrm{Mg}$-Li geothermometers in the case of immature waters (Orvin, Raud and Bjørnbein sites), which indicates their unsuitability for this type of waters.

The derived temperature values using Na-K-Ca, K-Mg, Ca-Mg, $\mathrm{Na}-\mathrm{Li}$ and silica geothermometers demonstrate the existence of two depth zones of thermal water formation in southern Spitsbergen, depending on the geological structure and the tectonic involvement of the given area. The first shallower zone, up to a depth of $1.1 \mathrm{~km}$, is associated with water circulation in the fault zones of metamorphosed early Paleozoic carbonate rocks of the Hecla Hoek succession in the region of the Hornsund fjord and Raudfjellet massif. This zone is characterized by reservoir water temperatures of about $40^{\circ} \mathrm{C}$. The second deeper zone of thermal waters in the Sørkappland area (Stormbukta area), with a temperature of about $80^{\circ} \mathrm{C}$, corresponds to the groundwater reservoir located at a depth of $2.3 \mathrm{~km}$. The thermal waters here are associated with sedimentary rocks of the late Paleozoic and early Mesozoic periods, where there are inflows of hot brines, mixing with the cold waters of the shallow circulation. The circulation depth in sedimentary rocks of southern Spitsbergen is the same as that in the north of the island in the Bockfjorden area.

\section{Acknowledgments}

This study was supported by a grant no. 0401/0163/20 from the University of Wrocław, Institute of Geological Sciences titled "Processes of recharge, flow and drainage of groundwater". Thanks are extended 
to Jin-Yong Lee (Editor-in-Chief of Episodes) and anonymous reviewers who helped improve the quality of this manuscript.

\section{References}

Amundsen, H.E.F., Griffin, W.L., and O'Reilly, S.Y., 1987, The lower crust and upper mantle beneath northwestern Spitsbergen: evidence from xenoliths and geophysics. Tectonophysics, v. 139, pp. 169-185. doi:10.1016/0040-1951(87)90095-3

Arnórsson, S., Gunnlaugsoon, E., and Svavarsson H., 1983, The chemistry of geothermal waters in Iceland III. Chemical geothermometry in geothermal investigations. Geochimica et Cosmochimica Acta, v. 47, pp. 567-577. doi:10.1016/0016-7037(83)90278-8

Banks, D., Sletten, R.S., Haldorsen, S., Dale, B., Heim, M., and Swensen, B., 1998, The thermal springs of Bockfjord, Svalbard: occurrence and major ion hydrochemistry. Geothermics, v. 27, pp. 445-467. doi:10.1016/ s0375-6505(98)00022-4

Banks, D., Siewers, U., Sletten, R.S., Haldorsen, S., Dale, B., Heim, and M., Swensen, B., 1999, The thermal springs of Bockfjorden, Svalbard: II: selected aspects of trace element hydrochemistry. Geothermics, v. 28, pp. 713-728. doi:10.1016/s0375-6505(99)00019-x

Birkenmajer, K., 1990, Geology of the Hornsund area, Spitsbergen. Explanations to the map 1:75.000 scale. University of Silesia Press, Katowice, Poland, $44 \mathrm{p}$.

Braathen, A., Bælum, K., Christiansen, H.H., Dahl, T., Eiken, O., Elvebakk, H., Hansen, F., Hanssen, T.H., Jochmann, M., Johansen, T.A., Johnsen, H., Larsen, L., Lie, T., Mertes, J., Mørk, A., Mørk, M.B., Nemec, W., Olaussen, S., Oye, V., Rød, K., Titlestad, G.O., Tveranger, J., and Vagle, K., 2012, The Longyearbyen $\mathrm{CO}_{2}$ Lab of Svalbard, Norway - initial assessment of the geological conditions for $\mathrm{CO}_{2}$ sequestration. Norwegian Journal of Geology, v. 92, pp. 353-376.

Can, I., 2002, A new improved $\mathrm{Na} / \mathrm{K}$ geothermometer by artificial neural networks. Geothermics, v. 31, pp. 751-760. doi:10.1016/s0375-6505(02) 00044-5

Chiba, H., and Sakai, H., 1985, Oxygen isotope exchange rate between dissolved sulfate and water at hydrothermal temperatures. Geochimica et Cosmochimica Acta, v. 49, pp. 993-1000. doi:10.1016/0016-7037(85)90314-x

Chiodini, G., Frondini, F., and Marini, L., 1995, Theoretical geothermometers and $\mathrm{P}_{\mathrm{CO} 2}$ indicators for aqueous solutions coming from hydrothermal systems of medium-low temperature hosted in carbonate-evaporite rocks. Application to the thermal springs of the Etruscan Swell, Italy. Applied Geochemistry, v. 10, pp. 337-346. doi:10.1016/0883-2927(95) 00006-6

Cooper, R.J., Wadham, J.L., Tranter, M., and Peters, N., 2002, Groundwater hydrochemistry in the active layer of the proglacial zone, Finsterwalderbreen, Svalbard. Journal of Hydrology, v. 269, pp. 208-223. doi:10.1016/s0022-1694(02)00279-2

D’Amore, F., and Arnórsson, S., 2000, Geothermometry. In: Arnórsson, S. (Eds.), Isotopic and Chemical Techniques in Geothermal Exploration Development and Use: Sampling Methods, Data Handling, Interpretation. International Atomic Energy Agency, Vienna, pp. 152-199.

Ellis, A.J., and Mahon W.A.J., 1967, Natural hydrothermal systems and experimental hot water/rock interactions (Part II). Geochimica et Cosmochimica Acta, v. 31, pp. 519-538. doi:10.1016/0016-7037(67)90032-4

Fouillac, C., and Michard G., 1981, Sodium/lithium ratio on water applied to geothermometry of geothermal reservoirs. Geothermics, v. 10, pp. 55-70. doi:10.1016/0375-6505(81)90025-0

Fouillac, C., Fouillac A.M., and Criaud A., 1990, Sulphur and oxygen isotopes of dissolved sulphur species in formation waters from the Dogger Geothermal Aquifer, Paris Basin, France. Applied Geochemistry, v. 5, pp. 415-427. doi:10.1016/0883-2927(90)90018-z

Fournier, R.O., 1973, Silica in thermal water: Laboratory and field investigations. Proceedings of the International Symposium on Hydrogeo- chemistry and Biochemistry, Washington DC, Clark, (1973), pp. 122139.

Fournier, R.O., 1977, Chemical geothermometers and mixing models for geothermal systems. Geothermics, v. 5, pp. 41-50. doi:10.1016/03756505(77)90007-4

Fournier, R.O., 1979, A revised equation for the $\mathrm{Na} / \mathrm{K}$ geothermometer. Geothermal Resources Council Transactions, v.5, pp. 1-16.

Fournier, R.O., and Potter R.W., 1979, Magnesium correction to the Na-KCa chemical geothermometer. Geochimica et Cosmochimica Acta, v. 43, pp. 1543-1550. doi:10.1016/0016-7037(79)90147-9

Fournier, R.O., and Truesdell, A.H., 1973, An empirical Na-K-Ca geothermometer for natural waters. Geochimica et Cosmochimica Acta, v. 37, pp. 1255-1275. doi:10.1016/0016-7037(73)90060-4

Fournier, R.O., and Truesdell, A.H., 1974, Geochemical indicators of subsurface temperature - 2. Estimation of temperature and fraction of hot water mixed with cold water. U.S. Geological Survey Journal Research, v. 2, pp. 263-270. doi:10.3133/ofr741032

Giggenbach, W.F., 1988, Geothermal solute equilibria. Derivation of NaK-Mg-Ca geoindicators. Geochimica et Cosmochimica Acta, v. 52, pp. 2749-2765. doi:10.1016/0016-7037(88)90143-3

Giggenbach, W.F., Gonfiantini, R., Jangi, B.L., and Truesdell, A.H., 1983, Isotopic and chemical composition of Parbati Valley geothermal discharges, NW-Himalaya, India. Geothermics, v. 12, pp. 199-222. doi:10.1016/ 0375-6505(83)90030-5

Haldorsen, S., Heim, M., and Lauritzen, S.E., 1996, Subpermafrost groundwater. Western Svalbard. Nordic Hydrology, v. 27, pp. 57-68. doi:10.2166/nh.1996.0019

Hałas, S., and Pluta, I., 2000, Empirical calibration of isotope thermometer $\delta^{18} \mathrm{O}\left(\mathrm{SO}_{4}{ }^{2}\right)-\delta^{18} \mathrm{O}\left(\mathrm{H}_{2} \mathrm{O}\right)$ for low temperature brines. Proceedings $\mathrm{V}$ Isotope Workshop. European Society for Isotope Research, Cracow, Poland, Book of abstracts, pp. 68-71.

Harland, W.B., 1997, The Geology of Svalbard. The Geological Society, London, $521 \mathrm{p}$.

Hoel, A., and Holtedahl, O., 1911, Lava sheets, volcanoes and hot springs near Baie Wood on Spitsbergen. Christiania: Jacob Dybwad Publisher, Oslo, 37 p (in French).

Humlum, O., Instanes, A. and Sollid, J.L. 2003, Permafrost in Svalbard: a review of research history, climatic background and engineering challenges. Polar Research, v. 22, pp. 191-215. doi:10.3402/polar.v22i2.6455

Kharaka, Y.K., and Mariner, R.H., 1989, Chemical geothermometers and their application to formation waters from sedimentary basins. In: Naeser, N.D., and McCulloh, T.H., (Eds.), Thermal History of Sedimentary Basins. Methods and case studies. Springer-Verlag, Berlin, pp. 99-117. doi:10.1007/978-1-4612-3492-0_6

Krawczyk, W.E., 1989, Thermal springs below Raudfjellet, South West Spitsbergen. Results of Investigations of the Polish Scientific Spitsbergen Expeditions. Acta Universitatis Wratislaviensis, v. VII (1069), pp. $67-74$.

Krawczyk, W.E., 1996, Karst springs in the region of Hornsund Fjord (SW Spitsbergen). Proceedings 23rd Polar Symposium, September 1996, Sosnowiec, Poland, pp. 51-66.

Kusakabe, D., and Robinson B.W., 1977, Oxygen isotopic fractionation factor between barite and $\mathrm{H}_{2} \mathrm{O}$ at hydrothermal temperature. Oxygen and sulphur isotope equilibria in the $\mathrm{BaSO}_{4}-\mathrm{HSO}_{4}-\mathrm{H}_{2} \mathrm{O}$ system from 110 to $350^{\circ} \mathrm{C}$ and its applications. Geochimica et Cosmochimica Acta, v. 44, pp. 1033-1040. doi:10.1016/0016-7037(77)90098-9

Lauritzen, S.E., and Bottrell S., 1994, Microbiological activity in thermoglacial karst springs, South Spitsbergen. Geomicrobiology Journal, v. 12, pp. 161-173. doi:10.1080/01490459409377983

Lauritzen, S.E., 1996, Interaction between glacier and karst aquifers: preliminary results from Hilmarfjellet, South Spitsbergen. Kras i Speleologia, v. 1527, pp. 17-27.

Lloyd, R.M., 1968, Oxygen isotopic behavior in the sulfate-water system. Journal of Geophysical Research, v. 73, pp. 6099-6110. doi:10.1029/ jb073i018p06099 
Migała, K., and Sobik, M., 1982, Discovery of thermal springs in the Raudfiellet region, SW Spitsbergen. Polar Research, v. 2, pp. 109-110. doi:10.3402/polar.v1982i2.7008

Mizutani, Y., and Rafter, T.A., 1969, Oxygen isotopic composition of sulphates - part 3. Oxygen isotopic fractionation in the bisulphate ion-water system. New Zeeland Journal of Science, v. 12, pp. 54-59.

Nieva, D., and Nieva, R. 1987, Developments in Geothermal Energy in Mexico-Part Twelve. A Cationic Geothermometer For Prospecting of Geothermal Resources. Heat Recovery Systems, v. 7, pp. 243-258. doi:10.1016/0890-4332(87)90138-4

Olichwer, T., Tarka, R., and Modelska, M., 2013, Chemical composition of groundwaters in the Horsund region, southern Spitsbergen. Hydrology Research, v. 44, pp. 117-130. doi:10.2166/nh.2012.075

Olichwer, T., and Tarka, R., 2018, Thermal and mineral springs of southern Spitsbergen. Polish Polar Research, v. 39, pp. 331-348. doi:10.24425/ 118750

Orvin, A.K., 1944, A bit about the springs in Svalbard. Norsk Geografisk Tidsskrift (Norwegian Journal of Geography), v. 10, pp. 16-38 (in Norwegian). doi:10.1080/00291954408621804

Pociask-Karteczka, J., 1990, The Thermal Orvin Spring below Mount Gnälberget (Hornsund, South Spitsbergen). Acta Universitatis Wratislaviensis, v. VII (1069), pp. 75-85.

Porowski, A., 2007, Significance and use of geothermometric study in exploration of low-enthalpy thermal waters. Technika Poszukiwań Geologicznych, v. 2, pp. 69-77 (in Polish).

Pulina, M., 1977, Remarks about karst phenomena in the south part of Spitsbergen. Kras i Speleologia, v. 1(X), pp. 104-125 (in Polish).

Salvigsen, O., and Hogvard, K., 1998, Gygrekjelda, a new warm spring in Bockfjorden. Polar Research, v. 17, pp. 107-109. doi:10.3402/polar. v17i1.6613

Szynkiewicz, A., Modelska, M., Buczyński, S., Borrok, D.M., Pratt, L.M., 2013, The polar sulfur cycle in the Werenskioldbreen, Spitsbergen: Possible implications for understanding the deposition of sulfate minerals in the North Polar Region of Mars. Geochimica et Cosmochimica Acta, v. 106, pp. 326-343. doi:10.1016/j.gca.2012.12.041

Szynkiewicz, A., Olichwer T., and Tarka R., 2020, Delineation of groundwater provenance in Arctic environment using isotopic compositions of water and sulphate. Journal of Hydrology, v. 580, 1242322. doi:10.1016/ j.jhydrol.2019.124232
Truesdell, A.H., 1976, Summary of Section III - Geochemical Techniques in Exploration. Proceedings the Second United Nations Symposium on the Development and Use of Geothermal Resources, San Francisco, CA, I, pp. LIII (53)-LXXIX (79).

Truesdell, A.H., and Fournier, R.O., 1977, Procedure for estimating the temperature of a hot water component in a mixed water using a plot of dissolved silica vs enthalpy. U.S. Geological Survey Journal Research, v. 5, pp. 49-52.

Van Everdingen, R.O., 1990, Groundwater hydrology. In: Prowse, T.D., and Ommanney C.S.L. (Eds.), Northern Hydrology: Canadian Perspectives. National Hydrological Research Institute NHRI Science Report no. 1, Environment Canada, Saskatoon, Canada, pp. 77-101.

Vagnes, E., and Amundsen, H.E.F., 1993, Late Cenozoic uplift and volcanism on Spitsbergen; caused by mantle Convection Geology, v. 21, pp. 251-254. doi:10.1130/0091-7613(1993)021<0251:lcuavo >2.3.co;2

Verma, M.P., and Santoyo E., 1997, New improved equations for $\mathrm{Na} / \mathrm{K}$, $\mathrm{Na} / \mathrm{Li}$ and $\mathrm{SiO}_{2}$ geothermometers by outlier detection and rejection. Journal of Volcanology and Geothermal Research, v. 79, pp. 9-23. doi:10.1016/s0377-0273(97)00024-3

Wadham, J.L., Hodson, A.J., Tranter, M., and Dowdeswell, J.A., 1998, The hydrochemistry of meltwaters draining a polythermal-based, high Arctic glacier, south Svalbard: I. The ablation season. Hydrological Processes, v. 12, pp. 1825-1849. doi:10.1002/(sici)1099-1085(19981015) 12:12<1825::aid-hyp669>3.0.co;2-r

Wawrzyniak, T., Osuch, M., Napiórkowski, J.J., and Westermann, S., 2016, Modelling of the thermal regime of permafrost during 1990-2014 in Hornsund, Svalbard. Polish Polar Research, v. 37, pp. 219-242. doi:10.1515/popore-2016-0013

Werenskiold, W., 1920, Physical geography of Spitsbergen. Naturen, v. 44, pp. 209-242 (in Norwegian).

Williams, J.R., and Van Everdingen, R.O., 1973, Groundwater investigations in permafrost regions of North America: a review. Proceedings Permafrost: North American Contribution. Second International Conference, Washington, D.C., National Academy of Sciences, pp. 435 446.

Zeebe, R.E., 2010, A new value for the stable oxygen isotope fractionation between dissolved sulfate ion and water. Geochimica et Cosmochimica Acta, v. 74, pp. 818-828. doi:10.1016/j.gca.2009.10.034

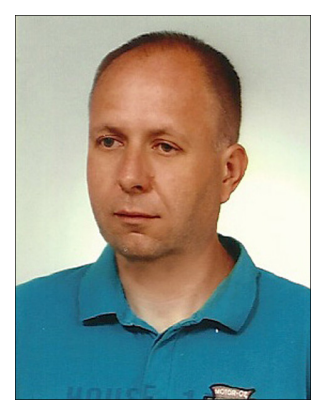

Tomasz Olichwer is an associate profesor at the Institute of Geology Sciences, Wroclaw University (Poland). He completed a Ph.D. thesis concerning the groundwater resources in the mountainous areas. Currently his research is focused on the climatic change impact on the groundwater resources in Poland. Additional interests include occurrence and circulation of groundwater in the polar regions.

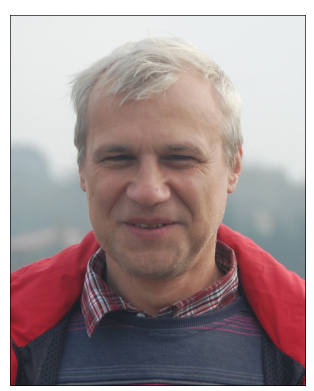

Robert Tarka is an associate profesor at the Institute of Geology Sciences, Wroclaw University (Poland). He completed a Ph.D. thesis concerning groundwater recharge. Currently his research is focused on occurrence and circulation of thermal waters in the polar regions 